\title{
Sons of a Minor God: Use of Reproductive Techniques by Single People and Gay Couples.
}

\author{
Filhos de um deus menor: uso de técnicas reprodutivas por \\ pessoas solteiras e casais gay.
}

\author{
Vera Lúcia Raposo / 黎慧華 ${ }^{1}$
}

\begin{abstract}
:
The progressive recognition of new family units (monoparental and same-sex families) as objects of legal protection is the product of enormous changes in society and in the way we understand our sexual choices. One of the consequences of this societaltransformationinvolves access to assisted reproductive techniques (ART).

Access to ART is traditionally allowed only for married people (obviously of the opposite gender, asopposite-sex marriage is still the regular standard and the only legal option in many parts of the world).Access to ART is sometimes allowed for heterosexual couples living in a de facto relationship. Today, some legal systems already permit the use of ART by single people and gay couples. Brazil is a good example, but in the remaining Latin-American countries as well as in Asia, restrictive solutions take precedence, although in most cases there is no proper regulation regarding ART. Most legal systems around the world still impose restrictions based on marital status and/or sexual orientation. Such legal prohibitions are problematic from a juridical perspective. In fact, it is recognised that reproduction is a fundamental right and a human right (instead of a mere aspiration or a whim), as has been stated by various courts around the world, including the Inter-American Court of Human Rights. This conclusion also results from the interpretation of some rights expressly recognised in national constitutions - namely, the right to privacy and the right to create a family - as including reproduction withintheir scope of protection, leading to the conclusion that reproduction is actually a constitutionally protected right. If this is so, any restriction on access to ART is actually limiting the fundamental right to reproduce, which can only be legally limited in the face of a particularly strong justification, such as the protection of the rights of others or of prominent constitutional values. To avoid criticism on constitutional grounds, the supporters of restrictive access to ART have invoked an apparently unbeatable argument: the protection of the future child. These advocates claim that if the child were born into a monoparental family or moreover into a same-sex family,then its well-being would be jeopardisedand its rights violated. However, this argument does not withstand strict constitutional scrutiny, as on the one hand it is too simplistic to
\end{abstract}

\footnotetext{
1 Assistant Professor of the Faculty of Law of Macau University, China 澳門大學法學院助理教授. Auxiliary Professor of the Faculty of Law of Coimbra University, Portugal. E-mail: vraposo@umac.mo
} 
justify limitations to constitutionally protected and fundamental rights and on the other hand no one has thus far adequately defineda 'child's best interest'. This paper intends to demonstrate that these are largely moral arguments that have no juridical foundations andare therefore incapable of attaching limitations to reproductive rights.

\title{
Keyword:
}

\author{
Reproductive Techniques, Reproductive Rights, Gender, Sexuality
}

\section{Resumo:}

O reconhecimento progressivo de novas unidades familiares (famílias monoparentais e do mesmo sexo) como objetos de proteção legal é o produto de enormes mudanças na sociedade e na forma como entendemos nossas escolhas sexuais. Uma das consequiências dessa transformação social envolve o acesso a técnicas de reprodução assistida (ART). O acesso à ART é tradicionalmente permitido apenas para pessoas casadas (obviamente do gênero oposto, o casamento entre os sexos é ainda o padrão regular e a única opção legal em muitas partes do mundo). O acesso às ART é, por vezes, permitido para casais heterossexuais que vivem em um relacionamento de facto. Hoje, alguns sistemas legais já permitem o uso de ART por pessoas solteiras e casais homossexuais. O Brasil é um bom exemplo, mas nos restantes países latinoamericanos e na Ásia, as soluções restritivas têm precedência, embora, na maioria dos casos, não haja uma regulamentação adequada em relação à ART. A maioria dos sistemas legais em todo o mundo ainda impõe restrições baseadas no estado civil e / ou na orientação sexual. Essas proibições legais são problemáticas a partir de uma perspectiva jurídica. De fato, é reconhecido que a reprodução é um direito fundamental e um direito humano (em vez de uma mera aspiração ou capricho), como já foi afirmado por vários tribunais do mundo, incluindo a Corte Interamericana de Direitos Humanos. Esta conclusão também resulta da interpretação de alguns direitos expressamente reconhecidos nas constituições nacionais - ou seja, o direito à privacidade e o direito de criar uma família - incluindo a reprodução no âmbito da proteção, levando à conclusão de que a reprodução é realmente um direito constitucionalmente protegido . Se assim for, qualquer restrição ao acesso à ART é, na verdade, limitando o direito fundamental de reprodução, que só pode ser legalmente limitado diante de uma justificativa particularmente forte, como a proteção dos direitos de terceiros ou de valores constitucionais proeminentes. Para evitar críticas por motivos constitucionais, os defensores do acesso restritivo à ART invocaram um argumento aparentemente imbecil: a proteção do futuro filho. Esses defensores afirmam que se a criança nascesse em uma família monoparental ou, além disso, em uma família do mesmo sexo, então seu bem-estar seria comprometido e seus direitos violados. No entanto, esse argumento não resiste ao escrutínio constitucional rigoroso, pois, por um lado, é muito simplista para justificar limitações aos direitos constitucionais e direitos fundamentais e, por outro lado, ninguém definiu adequadamente o "melhor interesse da criança". Este artigo pretende demonstrar que estes são, em grande parte, argumentos morais que não têm fundamentos jurídicos e são, portanto, incapazes de associar limitações aos direitos reprodutivos. 


\title{
Palavras chaves:
}

Técnicas reprodutivas; direito reprodutivo; gênero; sexualidade.

\section{The current scenario: Use of reproductive technologies by single people and gay couples in Asia and Latin America}

In Europe, Australia and North America, laws on assisted reproductive techniques (ART) tend to allow access by a new range of individuals, namely single people and gay couples, but the same is not true for both Asia and Latin America (with the exception of Brazil).

\begin{abstract}
Latin America is not homogeneous, and we can differentiate three scenarios.In Latin America, the majority of legal systems do not have specific legal regulations for ART. Thus, these decisions are left to the medical community,althoughthe legalnorms in place may in some way impose some limitations. ${ }^{2}$
\end{abstract}

The countries that do have some norms on ART are predominantly restrictive. Even if they do not necessarily ban single people and gay couples, ade factoban can be derived from other norms. In Mexico, for example,access to ART is only allowed for sterility cases that cannot be otherwise resolved, and the notion of sterility is understood in narrow terms. ${ }^{3}$ In Peru, law imposes a correspondence between the genetic and gestational mothers, which obviously leads to restrictions on the use of ART by males. ${ }^{4}$

In contrast to this scenario, in Brazil access to ART is extremely flexible. The main regulation is Resolution n. $2121 / 2015,{ }^{5}$ from the Federal Council of Medicine

\footnotetext{
${ }^{2}$ Cf. Hevia and Herrera Vacaflor, 2013: 52.

${ }^{3}$ Article 56 of Regulations to the General Health Law on Health Research [Reglamento de la Ley General de Saludenmateria de Investigacion para la Salud, http://www.salud.gob.mx/unidades/cdi/nom/compi/rlgsmis.html ].

Articulo 56 - "La investigaciónsobrefertilizaciónasistidasóloseráadmisiblecuando se aplique a la solución de problemas de esterilidad que no se puedan resolver de otramanera, respetándose el punto de vista moral, cultural y social de la pareja, aunsiéstedifiere con el de investigador".

4 Article 7 of General Health Law No. 26842 [ Ley General de Salud No 26842, http://www.wipo.int/edocs/lexdocs/laws/es/pe/pe060es.pdf].

Articulo 7 - "Toda persona tienederecho a recurrir al tratamiento de suinfertilidad, asícomo a procrearmediante el uso de técnicas de reproducciónasistida, siempre que la condición de madregenética y de madregestanterecaigasobre la misma persona".

5 Resolution $\quad$ n. 2121/2015, published in 22/09/2015 (http://www.portalmedico.org.br/resolucoes/CFM/2015/2121_2015.pdf).

Commenting on the current regulations in Brazil, Chaves, 2015.
} 
(which is not exactly a legal norm, but this issue won't be discussed here). ${ }^{6}$ The Resolution allows for the use of ART by single people and also byfemale couples (referred to in Brazil as 'female homoaffective unions'), disregarding an eventual declaration of infertility. In light of the Resolution it is clear that females - whether single or in a couple - are authorised to use ART. As for men not belonging to a heterosexual couple, the solution is unclear because in this scenario surrogacy is always required and the Resolution provides no clear indication that surrogacy is allowed for the benefit of men.However, there are indications that surrogacy might be allowed in favour of men: the current text of the Resolution uses the expression 'all capable people', while some earlier versions used the term 'all women', so, this modificationperhaps indicates an extension of the subjective scope of this regulation. In fact, homosexual male couples have been allowed to access a surrogate and thus to reproduce through ART, whereas single men have been excluded from ART (at least, we have no notice of any single man allowed to use these techniques).

Most ART regulations in Asia are extremely restrictive, and this legal approach seems to be in harmony with traditional societies.

For instance, in China the current laws, which are still very few in number, ban nearly everything, ${ }^{7}$ including surrogacy (within Greater China, surrogacy is only allowed in Hong Kong, but is restricted to heterosexual couples even there. ${ }^{8}$ ) Thus, single men and same-sex couples are obviously excluded from accessing reproductive techniques. Moreover, single women and female same-sex couples are prevented from using ART because they cannot benefit from sperm donations. ${ }^{9}$

Thailand probably represents the most liberal legal system in this regard. However, several limitations are still present. ${ }^{10}$ Thai society is known for being tolerant of homosexuality, and one may suppose that same-sex couples do not face legal obstacles in the use of reproductive techniques. However, this is not the case. In addition to guidelines from the Thai Medical Council, there is a new bill on reproductive technologies (Bill of Protection of Children Born from Assisted

\footnotetext{
${ }^{6}$ For a critic about the lack of legal norms on ART in Brazilian legal order see Raposo, 2011.

${ }^{7}$ Describing the restrictive Chinese regime, Qiao and Feng, 2014.

${ }^{8}$ For more on the regime of surrogacy in China, Macao, Hong Kong and Taiwan, see Raposo and U, 2017.

${ }^{9}$ Cf. Gong et al., 2009:645-652.

${ }^{10}$ Cf. Caamano, 2016: 588 ff. and Whittaker, 2016: 75 ff.
} 
Reproductive Technologies Act ${ }^{11}$ )thatindirectly prevents single people and same-sex couples from accessing ART. Although the Bill does not expressly ban thesescenarios, the use of expressions such as 'lawful spouse' results in the restriction of ART to legally married people, which in Thailand is defined by marriage to people of the opposite sex. ${ }^{12}$

\section{Thesis: Gay couples and single people cannot be prevented from using} ART

When reproduction results from sexual intercourse,it is practically free of restrictions because sexual practice is not bound by any limits other than those resulting from criminal law (in particular, sex crimes). ${ }^{13}$ That is, no one can prevent a man or a woman from having sex or, in the case of women, from gestating the resulting child.

However, when reproduction takes place through ART, legislators feels entitled to determine who can and cannot have children and, consequently, to impose prohibitions on accessing ART.

Two of the most frequent limitationsconcern civil status and sexual orientation, thus banning single people and same-sex couples from using ART. However, as we demonstrate, those limitations lack proper constitutional basis and thereforecannot be juridically accepted.

\subsection{First premise of the thesis: Reproduction is a fundamental right}

In the past, it was generally understood that the desire to have biologically related children resulted from a whim. Therefore, this aspiration could not demand any legal protection, much less be considered a fundamental right. ${ }^{14}$

However, this is a completely erroneous perspective on reproduction. The desire to procreate represents one of the most ancestral aspirations of humanity, a

\footnotetext{
${ }^{11}$ Bill of Protection of Children Born from Assisted Reproductive Technologies Act, B.E., Subject No. 167/2553 (http://www.thailawforum.com/thailand-draft-surrogacy-law/)

${ }^{12}$ Nevertheless, several ART clinics promote gay-friendly services. For instance, www.thailand surrogacy.com/blog/, referred inWhittaker, 2016: 75.

${ }^{13}$ Cf. Harris, 1998.

${ }^{14}$ Describing the traditional perspective, Deech, 2002: 593 ff. and Gafo, 1986: $54 \mathrm{ff}$.
} 
mixture of instinct and culture. The most desirable situation is the existence of a genetic link between the child and its parents, andwhen this is not possible there must at least existthe appearance of a genetic linkas happens with ART through procedures such as gamete donation and surrogate gestation. ART allows for the fulfilment of a desire that has been part of humankind since the beginning. People have always wanted to procreate (an essential aim forthe maintenance of the human species) and have often suffered when facedwithbiological or legal impediments.As reproduction is essential for human fulfilment, it is currently considered a fundamental right. ${ }^{15}$

Reproductive rightscan be described as a person's ability to make reproductive decisions without interference by the State. This statementbegan to be asserted by US courts at the beginning of the last century in cases such as Meyer v. Nebraska, ${ }^{16}$ Buck v. Bell, ${ }^{17}$ Skinner v. Oklahoma,${ }^{18}$ Griswold v. Connecticut,${ }^{19}$ Eisenstadt v. Baird ${ }^{20}$ and Roe v. Wade. ${ }^{21}$

However, most of thesecourt decisions related to the negative dimension of reproductive rights, i.e., the freedom not to have children, centring on the use of contraceptives andthe practice of abortion. In US caselaw, decisions on the positive dimension of the right to reproduce - the right to have children - are practically restricted to the condemnation of forced sterilisation. Nevertheless, those decisions about the right not to have children contain the nucleusof an idea that is perfectly transposable to the right to have children: matters relating to reproduction can only be decided by an individual, and the State cannot intrude beyond what is necessary to protect the rights of others or to safeguard fundamental community values, as occurs with any other right. This basic conclusion is validfor the decision to not procreate and the decision to procreateeither by means of sexual intercourse or medical procedure. $^{22}$

In recent times,this same idea was affirmed by the Inter-American Court of

\footnotetext{
${ }^{15}$ More developments about the qualification of reproduction as a fundamental right are found in Raposo, 2014, and the references therein contained.

${ }^{16}$ Meyer v. Nebraska, 262 U.S. 390 (1923).

${ }^{17}$ Buck v. Bell, 274 U.S. 200 (1927).

${ }^{18}$ Skinner v. Oklahoma, 316 U.S. 535 (1942).

${ }^{19}$ Griswold v. Connecticut, 381 U.S. 479 (1965).

${ }^{20}$ Eisenstadt v. Baird, 405 U.S. 438 (1972).

${ }^{21}$ Roe v. Wade, 410, U.S. 113 (1973).

${ }^{22}$ On the content of the right to reproduce see Raposo, 2014 and references therein referred.
} 
Human Rights, in the case Artavia Murillo v. Costa Rica, ${ }^{23}$ in which the Court was called upon to rule on the Costa Rican prohibitionof in vitro fertilisation (IVF) in force since $2000 .{ }^{24}$ According to one of the highest international human rights courts, such a ban violated a range of rights, including the right to private and family life, the right to form a family and the right to non-discrimination based on health, finances or gender.

The exercise of the right to reproduce depends on two factors: i) the transmission of a genetic code and ii) the intention to maintain a child and establish emotional ties. When a person meets these two requirements (although the first requirement can be replaced by gestation, as it also implies a biological relationship with the child), then a person can exercise the right to have children and the State cannot impose unlawful obstacles.Conversely, if there is solelya desire to raise a child but no biological connection exists, neither genetic nor through gestation (as frequently happens within ART), then the right to be exercised becomes the right to found a family (similar to what happens with adoption). Likewise, the State cannot impose unlawful restrictions on this right.

We mainly focus on reproductive rights, as when a single person or a same-sex couple intends to use ART there is usually a genetic and/or biological contribution from the person or persons involved. ${ }^{25}$

\subsection{Second premise of the thesis: Restrictions to fundamental rights have to be constitutionally grounded}

Fundamental rights do not necessarily belong to everyone.

Exclusions from fundamental rights can be grounded on several juridicalconstitutional mechanisms: the doctrine of 'immanent limits', the narrow understanding of the right's normative scope, or by means of constitutionally

\footnotetext{
${ }^{23}$ Case of Artavia Murillo et al v. Costa Rica, Inter-American Court of Human Rights, decision of November 28, 2012

${ }^{24}$ Comments to this case in Hevia\& Herrera Vacaflor, 2016: 724 ff.; Brena, 2013; Zegers-Hochschild et al., 2014

${ }^{25}$ In the case of lesbian couples, both elements can contribute genetically (for instance, one can provide the nucleus of the oocyte and the other the cytoplasm) or one contributes with her gametes and the other gestates the child.
} 
authorised legal restrictions. ${ }^{26}$ In light of the two first mechanisms - the theory of immanent limits and the narrow understanding of the right's normative scope - it may happen that the person gets immediately excluded from the right. In other words, it's not the case that there is a restriction on the exercise of the right, what happens is that the person is not considered a holder of that particular right.

In the case of reproductive rights, the first question to answer is whether everyone is a holder of these rights or if some are naturally and inevitably excluded from them.According to our understanding of reproductive rights, prima faciethe nature of the right includes all people because reproduction is a natural and universal desire.As a caveat, some people may be excluded from reproduction when considering the protection of the rights and interests of others or the safeguarding of values of special importance to the community.However, to firmly establish a prohibition of single people and gay couples to hold reproductive rights would require a specific justification. If the prohibition is not based on an effective collision with other constitutional rights or with higher values, but merelyreflects a certain idea about social morality (which obviously does not represent a value with constitutional grounding), then the restriction cannot be constitutionally accepted. In this case,we may be facing a violation of a fundamental right by denying the right to certain individuals without a proper constitutional basis. ${ }^{27}$

\subsection{Conclusion of the thesis: Single and gay people have a right to reproduce using $A R T$}

Reproduction is increasingly being considered a fundamental right and a human right, so any person is entitled to reproduction regardless of marital status or sexual orientation.

The qualification of reproduction as a fundamental right forces the reevaluation of the traditional legal limits imposed upon the use of ART.Most of these limitations are grounded on moral conceptions and onobsolete concepts of 'family' as a unity composed by a kind of holy trinity: father, mother and child.

\footnotetext{
${ }^{26}$ For more on these theories related to the interpretation of the scope of protection of fundamental rights and juridical-constitutional mechanisms to base restrictive interpretations, see Andrade, 2007 and Raposo, 2014: $662 \mathrm{ff}$.

${ }^{27}$ Cf. Trakman and Gatien, 1999: $125 \mathrm{ff}$.
} 
An argument usually invoked to establishlimitations on the use of ART by single people and gay couples is based on the protection of the future child, i.e., the person who will be born from the use of ART. However, there is no evidence that the so-called 'new families' violate children's rights. The best interest of the child is to be raised in a loving family, regardless of thefamily's composition.

\section{Limitations tothe use of ART derived from civil status}

Most legal systems restrict access to ART to married persons or at least to people in stable unions. ${ }^{28}$ However, ART makes it possible to destroy the seemingly inextricable link between sex and reproduction, thus enablingreproductionwithin different scenarios.

Monoparental families have become increasingly more common and planned, whereas in the past they were not planned, much less desired or even accepted. ${ }^{29}$ Yet, this possibility is limited by many legal systems, which exclude individuals (single, widowed, divorced) from parenthood by using ART based on the idea that marriage (or something resembling it) is the family mainstay.

This reasoning does not deny that the existence of a father and a motherrepresents a social value worthy of protection, and it does not intend to belittle the role of the father or mother. However, even when a family lacks one parent,it is still protected by law, and being a single parent does not diminish a person's ability to be a good parent.

Based on these considerations, several legal systems have opened the use of ART to any woman, regardless of her marital status, by means of gamete donation. This is the case of English law, ${ }^{30}$ Spanish law ${ }^{31}$ and, since 2016, Portuguese law. ${ }^{32}$

\footnotetext{
${ }^{28}$ Although de facto relationships differ from marriage by its supposedly greater volatility, most of the legal effects traditionally attributed to marriage were extended to these family relations.

${ }^{29}$ National Center for Lesbian Rights, 2016.

${ }^{30}$ Human Fertilisation and Embryology Act 1990 (as amendedbythe Human Fertilisation and EmbryologyAct 2008 ,

http://webarchive.nationalarchives.gov.uk/20130107105354/http://www.dh.gov.uk/en/Publicationsands tatistics/Publications/PublicationsLegislation/DH_080205

${ }^{31}$ Ley 14/2006, de 26 de mayo, sobre técnicas de reproducciónhumanaassistida[Law 14/2006, from 26th May, about techniques of human assisted reproduction], at https://www.boe.es/buscar/act.php?id=BOE-A-2006-9292

${ }^{32}$ Lei n. ${ }^{\circ} 32 / 2006$, de 26 de Julho, procriaçãomedicamenteassistida, alterada pela Lei n. ${ }^{\circ} 17 / 2016$, de 20 de Junho, alarga o âmbito dos beneficiários das técnicas de procriaçãomedicamenteassistida[Law n. 32/2006, from 26th July, about medically assisted reproduction, amended by Law n. 17/2016, from
} 
This is also the case in Brazil, where Resolution n. 2121/2015 permits the use of the PMA by single persons. However, the acceptance of single men (or male couples, for that matter) raises problematic issues: if no woman is present, men must resort to an egg donor and a surrogate, and surrogacy contracts are banned in most legal systems. This is why it is much easier to accept single women (or female couples) than single men (or male couples).

\section{Limitationsto the use of ART derived from sexual orientation}

The requirement of a heterosexual couple to use ART is related to the traditional concept of family as characterised bythe binomialgender construct of malefemale. ${ }^{33}$ Today, however, families appear in various forms and sizes, and it is difficult to identify a singular model.

Still, many dispute the availabilityof ART for same-sex couples, supposedly based on the best interests of the child and on its right to grow up in a family unit composed of one parent of each gender and no less than one of each.

It seems that growing up in a different family type would subject the child to shame and social ostracism. We cannot deny that many children are victimised by their ethnic or religious backgrounds, by parental health or economic conditionsand by parental sexual orientation. However, today it is well accepted that we can neither forbid people from reproducing based on their different ethnicities and religions, nor forbid sick people or people with limited economic resourcesfrom havingchildren. As such, why is it legitimate to forbid reproduction because of sexual orientation?

It has also been argued that growing up in a homosexual family determinesa person's future sexual orientation. This argument departs from an assumption that deserves discussion: that homosexuality is an undesirable sexual orientation and that it should therefore be avoided. However, the progressive change in social attitude towards homosexuality, which is evident in education, ${ }^{34}$ the media, entertainment and legislation, contradicts this conclusion.Even if it were so - a position we do not share

20th June, extends the scope of beneficiaries of medically assisted reproduction], at http://www.pgdlisboa.pt/leis/lei_mostra_articulado.php?nid=903\&tabela=lei_velhas\&nversao=3\&so_ $\underline{\text { miolo }}=$

${ }^{33}$ National Center for Lesbian Rights, 2016 and Raposo, 2009: 157 ff.

${ }^{34}$ Cf. Decoo, 2014. 
-we mustinquire into the originof homosexualpeoplewhoare now adults and who were raised by heterosexual parents. If it is truethat children become what they learn from their familial role models, where did current homosexual adults learn their sexual behaviour?

Traditionally, infertility was the only reason why people could use ART.Eventually anotherground was added, allowing its use by people suffering from severe pathologies,for whom ART can operate as a mechanism to prevent their transmission to offspring.Currently,same legal systemsdo not even demand any specific motivationsfor using ART.

Even when the law does not expressly impose the existence of a heterosexual relationship, this requirement may result from specific demands for accessing ART, namely be restricting ART solely to infertile people. In that casegay couples must present their case as one of infertility. ${ }^{35}$ According to the World Health Organization,infertility is a disease of the reproductive system defined by the inability to obtain a pregnancy after 12 months or more of regular intercourse without contraception. ${ }^{36}$ This definition does not specify that the two people incapable of reproducing must be of opposite sex, and if a same-sex couple were to have sexual intercourse across 12 months (or forever, for that matter) they would not be able to procreate, so this scenario actually satisfies the aforementioned criterion.

Some may say that gay people are not infertile because although they are unable to have children with their same-gender couple,they could reproduce with a personof the opposite gender. ${ }^{37}$ This is considered a mere relational infertility, easily solved by having sexual intercourse with a person of the opposite gender. However, other cases of relational infertility are commonly authorised forthe use of ART. We are referring to heterosexual couples in which the woman has the so-called 'hostile cervical mucus ${ }^{38}$ that prevents the man's sperm from penetrating into the woman's cervix. However, this does not happen with the spermatozoa of all other men, so it may be the case that if the woman has sexual intercourse with another man she can

\footnotetext{
${ }^{35}$ When the law also admits the use of ART to prevent the transmission of pathology, this is another justification that can be invoked, but only if the person that wishes to use ART actually suffers from a health condition susceptible of being transmitted. Therefore, claiming infertility issues continues to be a more suitable option.

${ }^{36}$ See Zegers-Hochschild et al., 2009: 2683 ff.

${ }^{37}$ Sustaining this argument, Loureiro, 2010: $273 \mathrm{ff}$.

${ }^{38}$ Cf. Nakano et al., 2015.
} 
become pregnant, with the same being valid for the man: if he has sexual intercourse with another woman, his sperm will survive. In these cases, the elements of the couple cannot procreate with each other, but they could be successful with another person. Although this also constitutes relational infertility,the law does not exclude this category of infertile people from using ART.

It can also be argued that the inability of same-sex couples to procreate is not a disease that can be understood as a deviation from normality, as in their case it is a choice. However, for this argument to be unassailable, we would have to establish a univocal concept of 'disease', which has not yet been accomplished. Is drug addiction a disease or a choice? ${ }^{39}$ Is paedophilia a disease or a choice? ${ }^{40}$ What about menopause? ${ }^{41}$ If we consider fertility issues, we can conclude that menopausal women are often treated as infertile andtherefore allowed to use ART, even when they did not have children during their fertile period due totheirlife choices.

Moreover, modern ART regulations tend to open reproductive techniques to new grounds other than infertility and the risk of transmitting a disease, such as the reproduction of menopausal women (though itremains questionable if age-related infertility is 'real infertility') and post-mortem reproduction. In summary, there are sound reasons for allowing the use of ART as a mechanism to facilitate same-sex reproduction. $^{42}$

\section{Limits to reproductive rights as fundamental rights}

Some of the refusals to accept the expansion of reproductive rights lie in the fears of unlimited claims for new scenarios and of parental disregard for the wellbeing of children. However, this will only be possible if these rights wereconceived of as unlimited, embracing and allowing everything. If no other fundamental right, and not even the right to life, is today regarded as an absolute right, then why would reproductive rights be considered unlimited? Theserights are bound by the same limitations as other fundamental rights, perhaps even more so, given that they

\footnotetext{
${ }^{39}$ Branch, 2011: $263 \mathrm{ff}$.

${ }^{40}$ Moen, 2015: $111 \mathrm{ff}$.

${ }^{41}$ Lah, 2012.

${ }^{42}$ Sustaining that the ban of same-sex couples from ART lacks sufficient juridical basis see Callahan, 1997: 188 ff.; Campbell, 2002; Robinson, 1997: 217 ff.; Raposo, 2005: 111 ff.; Raposo, 2007: 37 ff.; Raposo, 2014: 969 ff.
} 
intrinsically involve other individuals in addition to the rightsholders, namely the children.

There is a distinction between being entitled with a rightand the effective exercise of this right. Therefore, although everyone, regardless of individual conditions, has the right to reproduce, in some situations people cannot exercise their reproductive rights given the limitations imposed by the rights of others, or by values considered superior.

Not all legislative interventions in the field of fundamental rights necessarily have a limitative nature (in the sense of restricting the scope of protection of the right). Some legislative interventions are merely conditioning, insofar as they influence the mode of their exercise but not their content. For instance, there are limitations derived from the particular situation of the subject in question. The most flagrant case is that of detainees, as in prisons where marital visits are not authorised sexual reproduction is obviously limited (even medically assisted reproduction has been denied, which be seen as an actual limitation and arguably an unlawful one. ${ }^{43}$ )

Other kinds of limits are manifestations of the right's immanent limits that are intrinsic to it and that, a priori, delineate its scope of protection. For instance, the right to reproduce applies only whenever persons use their own gametes.Otherwise, the right in question is the right to create a family, such as happens with adoption and any situation in which the person is not biologically connected with offspring, except if there is a biological relation derived from gestation. Another requisite regarding the right to reproduce is the desire to raise a child. This excludes gamete donors, who do not exercise the right to reproduce but rather the right to dispose of their own bodies. $^{44}$

Moreover, immanent limits to reproductive rightsalso exclude criminal conducts. Therefore, the exercise of reproductive rights cannot lead to a criminally prohibited situation ${ }^{45}$ such as incest or reproducing with a minor, the latter of which represents a crime of sexual child abuse.

Additional limits express no more than the solution to a conflict between

\footnotetext{
${ }^{43}$ Case E.L.H. and P.B.H. v. The United Kingdom n. 32094/96 and 32568/96, 22 October 1997, ComEDH.

${ }^{44}$ Stating these two requisites for reproductive rights - the genetic bond and the desire to raise the child - see Raposo, 2014: $108 \mathrm{ff}$.

${ }^{45}$ Cf. Vega Gutiérrez, 1998: 32-33.
} 
rights or between constitutional rights and values. For instance, a woman cannot be allowed to transfer to her uterus previously cryopreserved embryos without the consent of the embryo's genetic father (excluding the donors, whose authorisation is irrelevant for uterine transference) because her right to reproduce (the woman) is limited by his right to reproduce (the man). ${ }^{46}$

Today, it is commonly accepted that any right, no matter how fundamental, is not absolute. ${ }^{47}$ Therefore, if we accept that reproduction is a right, then we also have to accept its limitations ${ }^{48}$ which may result from the balance between reproduction and other rights ${ }^{49}$ or even imposed byhuman dignity. ${ }^{50}$ In sum, rights holders cannot do whatever they want with their rights.

When imposing limitations on reproductive rights, we should never abandon the legal domain and enter into the moral one. However, most limitations regarding access to ART are based on moral considerations, which are clearly insufficient justifications for restricting fundamental rights.

\section{Limitations to reproduction and the child's best interest}

It has not been demonstrated that monoparental families and families based on same-sex couples actually compromise the well-being of the child, nor is one specific family model represented by the inclusion of one father and one mother.

Based on the (erroneous) assumption that each child must necessarily have a father and a mother,some people claima legal right to 'biparentality', ${ }^{51}$ which may find some basis in the norms that reinforce parents'obligationsto care for their children. However, there are two caveats to this reasoning. On the one hand, these rules refer to a duty that is incumbent upon the legal parents, whomever they may be, but they do not require legal parents tobe a man and a woman. On the other hand, the primary intention of these standards is to ensure that someone cares for the child, regardless of who the caregivers are. In short, there is no right to biparentality, just a

\footnotetext{
${ }^{46}$ For more on the need of a mutual agreement for embryonic uterine transference, Raposo, 2008: 55.

${ }^{47}$ However, some authors sustain the existence of some unlimited rights, namely, the right to life and right to be treated in a dignified way (cf. Gewirth, 1981: $1 \mathrm{ff}$.).

${ }^{48}$ Cf. Gomez Sanchez, 1994: 59.

${ }^{49}$ Cf. Häberle, 2003: 68.

${ }^{50}$ Cf. Crorie, 2004: 167.

${ }^{51}$ For instance, Aguilar, 2000: 655 ff. and Andorno, 2016: $38 \mathrm{ff}$.
} 
right of the child to be loved and educated by someone. For some, these caregivers are preferably the biological parents, when they exist and are not prevented from exertingtheir parental authority, but acorrespondence between genetic parents and legal parents it is not imperative. Similarly, there is no specific right to have, in the birth register, the name of a man as the father and the name of a woman as the mother, or the right to be raised within a certain type of family formation.

We can agree that reproductive rights cannot become a source of harm to the child to be born. However, theimplications of this conclusion are problematic because of the difficulty in defining a child's best interests, and in defining what can be considered an injury in a particular case..$^{52}$

\section{Limitations to reproduction and the principle of equality}

The law does not have to provide equal treatment for everyone. Quite the opposite, sometimes it is the veryprinciple of equality that leads to differentiated treatment to respect the differences between situations: treat the equal as equal, but the unequal as unequal. ${ }^{53}$

This reasoning faces a challenge related to the definition of what is equal and what is not equal. For example, for the purposes of parenting andthe ability to provide a healthy and safe environment for a child's growth, is a single person 'equal' to a married person? Is a homosexual couple different from a heterosexual couple? What is more distant from the ideal concept of family: monoparental families and families grounded on same-sex couples, or families with physically and emotionally abusive members?

If the objective is to prevent 'bad parents' from having kids, then how can we define a 'bad parent'? Why ban single people and gay couples and instead allow people exhibitingpotentially dangerous behaviour neara child? Why not ban people such as workaholics, whose behaviour may be directly detrimental to a child's life, even if they are respected by today's society?

Thatcourtscurrently tend to condemn the use of sexual orientation as a criterion to define a'proper parent' or to remove parental power in case of divorce shows that differential treatment based on these grounds is unjustified. For instance,

\footnotetext{
${ }^{52}$ For more on the difficulties in defining the child's best interest, see Raposo, 2016: $250 \mathrm{ff}$.

${ }^{53}$ For more on the multiple dimensions of the principle of equality, see Albuquerque, 1993.
} 
in the case Salgueiro da Silva Mouta v. Portugal ${ }^{54}$ the European Court of Human Rights condemned the Portuguese state because of a Portuguese judicial decision that removed the parental power of a gay father invoking his sexual orientation.

Problems in terms of equality also arise regarding differential treatment between those who reproduce through coital sex and those who reproduce with the assistance of medical techniques. In fact, in the context of coital reproduction, future parents are exempt from any kind of scrutiny (if this were not the case, a good part of the population would be prevented from having children). In contrast, several requisites are required for people who want or need to use ART (note that sometimes what is considered a 'want' is actually a 'need'), andthese requisites may include an assessment of their capacity to be 'good parents', whatever that may be.

The argument stated to justify differential treatment is related to the involvement of the State: in coital reproduction everything is more private and the State rarely intervenes, whereas in ART the State is called to provide medical means. However, things are not always so clear. On the one hand, pregnancies derived from sexual reproduction often use medical State resources because many pregnant womenrely on the national health servicesfor pre-natal care. On the other hand, when patients pay for their own reproductive treatment, they are not using public resources and the situation is the same as in any other gestation.

\section{Limitations to reproduction and protection of the traditional family model}

Another justification usually invoked against the liberalisation of ART is the preservation of the family model upon whichthe traditional form of society is based. Both families and societies are supposedly threatened by the proliferation of new family models.

However, today's society is far from being based on a single family model. ${ }^{55}$ On the contrary, familiesnow appear in various forms, shapes and sizes, and all of them deserve legal protection. ${ }^{56}$

In hindsight, the supposed 'perfect trinity' of the traditional family was not so

\footnotetext{
${ }^{54}$ Case Salgueiro da Silva Mouta v. Portugal, n. 33290/96, 21 December 1999, ECtHR

${ }^{55}$ Cf. Rodriguez and Gomes, 2012: $29 \mathrm{ff}$.

56For more on the so-called new families, see Raposo, 2015: 123-138.
} 
perfect; otherwise communities would not have needed to accommodatealternative models of the family.

If the one-dimensional concept of family has been transformed into various family formations, all different but all of them 'family', then what arguments remain to prevent people from using ART to reproduce and constitute a family?

\section{Final remarks}

Reproductive rights certainly have limits, but only those limits that can be justified on legal grounds are acceptable, such as the protection of the rights of others or relevant constitutional values. In contrast, mere moral considerations of aperson's private conduct, especially sexual conduct, have no place here.

The fallibility of the criteria used to limit reproductive rights and their connotations with moralistic considerations are irrelevant in today's world because they are based on an obsolete understanding of the concept of 'family'. Families based on a single parent or on a same-sex couplealso represent families.

Turning away moralistic reasons, what other argument - congruent with fundamental rights theory - persists? We believe that none does so.

"All happy families are alike; each unhappy family is unhappy in its own way."

(Leo Tolstoy, Anna Karenina)

\section{References:}

Aguilar, Francisco (2000). O Princípio da Dignidade da Pessoa Humana e a Determinação da Filiação em Sede de Procriação Medicamente Assistida. Revista da Faculdade de Direito da Universidade de Lisboa, 41(2): 655-713.

Albuquerque, Martim de (1993). Da Igualdade: Introdução à Jurisprudência. Almedina, Coimbra.

Andorno, Roberto (2016). A Human Rights Approach to Bioethics. In: Bioethical Decision Making and Argumentation (Bermúdez, Pedro Serna; Seoane, José Antonio Eds.). Springer, Switzerland: 31-41. 
Andrade, José Carlos Vieira (2007). Os Direitos Fundamentais na Constituição Portuguesa de 1976 ( $3^{\text {rd }}$ ed.). Almedina, Coimbra.

Branch, Marc N. (2011). Drug Addiction. Is It a Disease or Is It Based on Choice? A Review of Gene Heyman's Addiction: A Disorder of Choice. Journal of the Experimental Analysis of Behavior 95.2: 263-267

Brena, I. (2013). Ruling of the Inter-American Court of Human Rights, the Case of Artavia Murillo et al (In Vitro Fertilization) v. Costa Rica; New Hopes for the Reproductive Freedom in Latin America. Rev Derecho Genoma Hum 38: 149-66.

Caamano, Jessica M. (2016). International, Commercial, Gestational Surrogacy Through The Eyes Of Children Born To Surrogates In Thailand: A Cry For Legal Attention. Boston University Law Review 96(2): 571-607.

Callahan, Sidney (1997). Gay, Lesbians and the Use of Alternative Reproductive Technologies. In: Feminism and Families (Thinking Gender) (Nelson, H. ed.). Routledge,New York: 188-204.

Campbell, J. (2002). I Have Two Moms, One Dad and Two Parents. Australian Population Association, 11th Biennial Conference, Sydney 1-4 October, 2002, at http://www.apa.org.au/upload/2002-3B_Campbell.pdf

Chaves, Marianna (2015). Famílias Ectogenéticas - Os Limites Jurídicos para Utilização de Técnicas de Reprodução Assistida. In: Anais do X Congresso Brasileiro de Direito de Família - Famílias Nossas De Cada Dia: 309-339, at https://www.academia.edu/27632388/FAM\%C3\%8DLIAS_ECTOGEN\%C3\%89TIC AS_OS_LIMITES_JUR\%C3\%8DDICOS_PARA_UTILIZA\%C3\%87\%C3\%830_D E_T\%C3\%89CNICAS_DE_REPRODU\%C3\%87\%C3\%83O_ASSISTIDA

Decoo, Ellen (2014). Changing Attitudes Toward Homosexuality in the United States from 1977 to 2012. All Theses and Dissertations. Paper 4091.

Deech, Ruth (2002). Losing Control? - Some Cases. In: Biomedicine, the Family and Human Rights (Meulders-Klein, M.-T.; Deech, R.; Vlaardinger broek, P. eds.). Kluwer Law International, The Hauge, London, New York: 581-598.

Gafo, Javier (1986). Nuevas Técnias de Reproducción Humana. Publicaciones de la Universidad Pontificia Comillas, Madrid.

Gewirth, Alan (1981). Are there any Absolute Rights? The Philosophical Quarterly, 31(122): 1-16.

Gomez Sanchez, Yolanda (1994). El Derecho a la Reproducción Humana. Marcial Pons, Madrid.

Gong, D.; Y.-L., Liu; Zheng, Z.; et al. (2009). An Overview on Ethical Issues about Sperm Donation. Asian Journal of Andrology 11(6):645-652. doi:10.1038/aja.2009.61. 
Häberle, Peter (2003). La Libertad Fundamental en el Estado Constitucional. Editorial Comares, Granada.

Harris, John (1998). Rights and Reproductive Choice. In: The Future of Human Reproduction: Ethics, Choice and Regulation (Harris, J.; Holm, S. eds.). Clarendon Press, Oxford: 5-37.

Hevia, Martin; Herrera Vacaflor, Carlos (2013). The Legal Status of In Vitro Fertilization in Latin America and the American Convention on Human Rights. Suffolk Transnational Law Review 36(1): 51-88.

Hevia, Martin; Herrera Vacaflor, Carlos (2016). The Lingua Franca of Reproductive Rights: The American Convention on Human Rights and the Emergence of Human Legal Personhood in the New Civil and Commerce Code of Argentina. U. Miami Int'l \& Comp. L. Rev. 23: 687-740.

Lah, Jennifer (2012). It's Menopause - Not Infertility, athttp://www.newfeminism.co/2012/04/its-menopause-not-infertility/, posted on April $\underline{30,2012 .}$

Loureiro, João (2010). Há Mais Vida para Além da Letra: A Questão das Chamadas (Homo) Parentalidades e a (Re)Leitura da Lei de Procriação Medicamente Assistida. Revista Portuguesa de Bioética 11: 273-293.

Mac Crorie, Benedita (2004). O Recurso ao Principio da Dignidade da Pessoa Humana na Jurisprudência do Tribunal Constitucional. In: Estudos em Comemoração do Décimo Aniversário da Licenciatura em Direito da Universidade do Minho. Almedina, Coimbra: 151-174.

Moen, Ole Martin (2015). The Ethics of Pedophilia. Etikkipraksis - Nordic Journal of Applied Ethics, [S.1.], n. 1: 111-124, at http://www.ntnu.no/ojs/index.php/etikk_i_praksis/article/view/1718/1836

Nakano, Fabiana Y.; Leão, Rogério de Barros F.; Esteves, Sandro C. (2015). Insights into the Role of Cervical Mucus and Vaginal PH in Unexplained Infertility. Medical Express 2(2):1-8, at http://www.scielo.br/scielo.php?script=sci_arttext\&pid=S2358$\underline{04292015000200007}$

National Center for Lesbian Rights. (2016), Legal Recognition of LGBT Families, at http://www.nclrights.org/wpcontent/uploads/2013/07/Legal_Recognition_of_LGBT_Families.pdf

Qiao, Jie; Feng, Huai L. (2014). Assisted Reproductive Technology in China: Compliance and Non-Compliance. Translational Pediatrics 3.2: 91-97.

Raposo, Vera Lúcia (2005). Direitos Reprodutivos. Lex Medicinae 2(3): 111-131.

Raposo, Vera Lúcia (2008). O Dilema do Rei Salomão: Conflito de Vontades Quanto ao Destino dos Embriões Excedentários. Lex Medicinae 5(9): 55-79.

Raposo, Vera Lúcia (2009). Crónica de um Casamento Anunciado. Revista do Ministério Público 30(120): 157-190. 
Raposo, Vera Lúcia (2011). A Idade da Inocência: Podemos Contratos de Gestação Sobreviver sem Lei Reguladora?.Revista Jurídica UNISEB 1(1): 143-172.

Raposo, Vera Lúcia (2014). O Direito à Imortalidade (O Exercício de Direitos Reprodutivos Mediante Técnicas de Reprodução Assistida e o Estatuto Jurídico do Embrião In Vitro).Coimbra, Almedina.

Raposo, Vera Lúcia (2015). The True Colours of Reproductive Rights, Especially in the Context of Rainbow Families. In: Aspects Légaux et Éthiques du Commencement de la Vie / Legal and Ethical Aspects Regarding the Beginning of Life (Duguet, Anne Marie coord.). Les Études Hospitalières Édition, Bordeaux: 123-138

Raposo, Vera Lúcia (2016). Os Intocáveis - Sobre a (Ir)Responsabilidade dos Pais por Violação de Deveres Reprodutivos no Código Civil de Macau. In: Um Diálogo Consistente: Olhares Recentes sobre Temas do Direito Português e de Macau, Vol I (Io Cheng, Tong; Fonseca, Hugo Duarte eds.). Associação de Estudos e Jurisprudência de Macau, Macau: 250-274.

Raposo, Vera Lúcia; Sio Wai, U (2017). Surrogacy In Greater China: The Legal Framework in Taiwan, Hong Kong, Macao, and Mainland China. UCLA Pacific Basin Law Journal 34: 135-148

Raposo, Vera Lúcia. (2007). Em Nome do Pai (...Da Mãe, dos Dois Pais, e das Duas Mães) - Análise do art. $6^{\circ}$ da Lei 32/2006. Lex Medicinae4(7):37-52.

Robinson, Bambi (1997). Birds Do it. Bees Do it. So Why not Single Women and Lesbians?.Bioethics11 (3-4): 217-227.

Rodriguez, Brunella Carla; Gomes, Isabel Cristina. (2012). Novas Formas de Parentalidade: Do Modelo Tradicional à Homoparentalidade. Bol. Psicol 62(136): 2936.

Trakman, Leon; Gatien, Sean (1999). Rights and Responsibilities. University of Toronto Press, Toronto, Buffalo, London.

Vega Gutiérrez, Ana (1998). Los Derechos Reproductivos en la Sociedad Postmoderna: Una Defensa o una Amenaza contra el Derecho a la Vida?. In: Derechos Reproductivos y Técnicas de Reproducción Asistida(Vidal Martínez, Jaime; Benitez Ortuzar, José; Vega Gutiérrez, Ana eds.). Editorial Comares, Granada: 1-52. Whittaker, Andrea (2011). Cross-Border Assisted Reproduction Care in Asia: Implications for Access, Equity and Regulations. Reproductive Health Matters 19(37): 107-116.

Whittaker, Andrea (2016). From 'Mung Ming' to 'Baby Gammy': A Local History of Assisted Reproduction in Thailand. Reproductive Biomedicine \& Society Online 2:71 -78 .

Zegers-Hochschild, F.; Adamson, G. D.; Mouzon. J., et al. (2009). The International Committee for Monitoring Assisted Reproductive Technology (ICMART) World 
Health Organization (WHO). Revised Glossary on ART Terminology. Hum. Reprod 24(11): 2683-2687.

Zegers-Hochschild, Fernando; Dickens, Bernard; Dughman, M. E; Manzur, Sandra. (2014). Human Rights To In Vitro Fertilization. JBRA Assisted Reproduction 18(1): 27-31.

Recebido em : 27/09/2017.

Aprovado em: 10/10/2017 